\title{
Erratum to: The Social Life of Memory
}

\author{
Norman Saadi Nikro and Sonja Hegasy
}

Erratum to:

N.S. Nikro and S. Hegasy (eds.), The Social Life of Memory, Palgrave Studies in Cultural Heritage and Conflict, https://doi.org/10.1007/978-3-319-66622-8

The original version of the book was inadvertently published missing out some of the corrections provided by author in Frontmatter, Chapters 1, 4 and 8 , which have been now incorporated.

The updated online version of these chapters can be found at https://doi.org/10.1007/978-3-319-66622-8_1, https://doi.org/10.1007/978-3-319-66622-8_4, https://doi.org/10.1007/978-3-319-66622-8_8 and https://doi.org/10.1007/978-3-319-66622-8

(C) The Author(s) 2018 El

N.S. Nikro and S. Hegasy (eds.), The Social Life of Memory, Palgrave Studies in Cultural Heritage and Conflict, https://doi.org/10.1007/978-3-319-66622-8_10 